\title{
Plate-screw and screw-washer stability in a Schatzker type-I lateral tibial plateau fracture: a comparative biomechanical study
}

\section{Comportamento biomecânico de dois tipos de fixação usados como suporte na fratura do platô tibial lateral do tipo I de Schatzker}

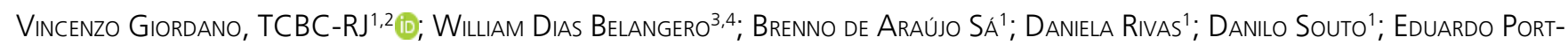
nol'; José Ricardo Mariolani ${ }^{4}$; Hilton Augusto KoCh5.

\begin{abstract}
A B S T R A C T
The aim of this study was to evaluate the biomechanical role of both a non-locking two-hole small fragment dynamic compression plate with 3.5-mm screws and a 4.5-mm cortical screw with a washer applied to a Schatzker type-I tibial plateau fracture. Sixteen right synthetic tibiae were used to create an anterolateral shear tibial plateau fracture (Schatzker type-I fracture). Eight models were fixed with a small fragment non-locked straight dynamic compression plate with one 3.5-mm bicortical screw (plate-screw construction) and eight models were fixed with a 4.5-mm cortical screw and a washer (screw-washer construction), both inserted at $1.0 \mathrm{~mm}$ distal to the apex of the fracture. Specimens were tested up to the onset of yielding at a constant strain rate of $5.0-\mathrm{mm} / \mathrm{min}$. Stiffness ranged from $311.83 \mathrm{~N} / \mathrm{mm}$ to $199.54 \mathrm{~N} / \mathrm{mm}$, with a mean + SD of $260.32+33.8 \mathrm{~N} / \mathrm{mm}$ in the plate-screw construction, and from $290.34 \mathrm{~N} / \mathrm{mm}$ to $99.16 \mathrm{~N} / \mathrm{mm}$, with a mean $+S D$ of $220.46+63.12 \mathrm{~N} / \mathrm{mm}$ in screw-washer construction. There was no significant difference $(\mathrm{p}=0.172)$. Use of a two-hole small-fragment non-locked plate with one 3.5-mm cortical screw or a 4.5-mm cortical screw with a washer applied at $1.0 \mathrm{~mm}$ distal to the apex of the fracture as buttressing present similar stiffness in terms of preventing axial displacement in synthetic tibiae models tested up to the onset of yielding.
\end{abstract}

Keywords: Tibial Plateau. Biomechanical Study. Fixation Techniques.

\section{INTRODUCTION}

L ateral split fragment with or without comminution Lcorresponds approximately to 40.0 to $45.0 \%$ of all tibial plateau fractures ${ }^{1-3}$. In this demographic distribution, Schatzker type-I tibial plateau fracture is far less common, accounting for only 3.5 to $9.0 \%$ of these injuries ${ }^{1-3}$. This particular tibial plateau fracture type is usually observed in the younger population, mainly due to a denser cancellous bone which resists impaction ${ }^{4}$. These patients are most likely to suffer traffic accidents and sport injuries, which cause a combination of axial and valgus loading forces leading to a shearing displacement of the lateral tibial condyle ${ }^{2,5}$. Normally the knee is extended or semi-extended, which makes an anterolateral $(\mathrm{AL})$ fragment much more common than a posterolateral one'.

In general, pure split AL tibial plateau fracture can be addressed by anatomic reduction either closed or open and rigid internal fixation with two $6.5-\mathrm{mm}$ cancellous or 7.0-mm cannulated lag-screws ${ }^{4,6-8}$. As an alternative, one partially and one fully threaded 6.5$\mathrm{mm}$ cancellous screws can be used ${ }^{9}$. Some authors recommend the use of an AL buttress plate or a screw and washer at the apex of the fracture to prevent axial displacement when a long split is identified or there is comminution at its metaphyseal base $\mathrm{b}^{4,7,8,10}$. However, to the best of our knowledge the buttressing effect of both plate-screw and screw-washer construct on fracture displacement was not yet been investigated biomechanically.

Our hypothesis was that plate-screw construct would provide a stiffer construction for fixation of an $\mathrm{AL}$ Schatzker type-I tibial plateau fracture (Kfuri-Schatzker type I A). The purpose of this study was to evaluate the role of both a non-locking small fragment dynamic

1 - Miguel Couto Municipal Hospital, Orthopedics and Traumatology Service Nova Monteiro - Rio de Janeiro - RJ - Brazil 2 - Clínica São Vicente, Rede D'or São Luiz, Orthopedics - Rio de Janeiro - RJ - Brazil 3 - Faculty of Medical Sciences, University of Campinas (UNICAMP), Department of Orthopedics - Campinas - SP - Brazil 4 - Faculty of Medical Sciences, University of Campinas (UNICAMP), Biomaterials Laboratory in Orthopedics (LABIMO) - Campinas - SP - Brazil 5 - Federal University of Rio de Janeiro (UFRJ), Department of Radiology - Rio de Janeiro - RJ-Brazil 
compression plate with 3.5-mm screws and a 4.5-mm cortical screw with a washer applied to the anterolateral apex of a Schatzker type-I tibial plateau fracture on loads at the implant-bone interface.

\section{METHODS}

\section{Anterolateral fracture preparation}

Sixteen right synthetic tibiae (Model 64177, Nacional Ossos, Brazil) from a single manufacturing batch were used to create an anterolateral shear tibial plateau fracture (Schatzker type-I fracture / Kfuri-Schatzker type $(A)^{11,12}$. A fracture line was draw based on the threedimensional computed tomographic study by Chen et al., who showed the average fracture line angle of the AL Schatzker type-I tibial plateau fracture to be $145.92^{\circ}$ $\pm 16.06^{\circ 1}$. The cut was done with a band saw starting from the articular surface and exiting the anterolateral side of the synthetic model, making a fracture line angle of $145^{\circ}$ (Figure 1).

The fracture was directly reduced with a large pointed reduction clamp and fixed with two 6.5-mm cancellous screws with $32-\mathrm{mm}$ thread and washers in a lag-screw fixation. Screws were positioned from lateral to medial, parallel to the articular line, five millimeters from the lateral rim of the tibial plateau. Additional buttressing fixation was performed in all bone models at the apex of the fracture. Eight models were fixed with a two-hole small fragment non-locked straight dynamic compression plate with one 3.5-mm bicortical screw inserted at $1.0 \mathrm{~mm}$ distal to the apex of the fracture (plate-screw construction group) and eight models were fixed with a 4.5-mm bicortical screw inserted at $1.0 \mathrm{~mm}$ distal to the apex of the fracture and a washer (screwwasher construction group). All implants (plates, screws, and washers) were from Ortosintese (Jaraguá, Brazil). Plates were bent to fit the contour of the metaphysis of the anterolateral tibial plateau. Anteroposterior (AP) and lateral fluoroscopic images were obtained for each tibial plateau-implant construct to check for any incongruency on the position of the screws (Figure 2).

The models were sawed with a length of 250-mm for adjustment to the biomechanical testing machine.
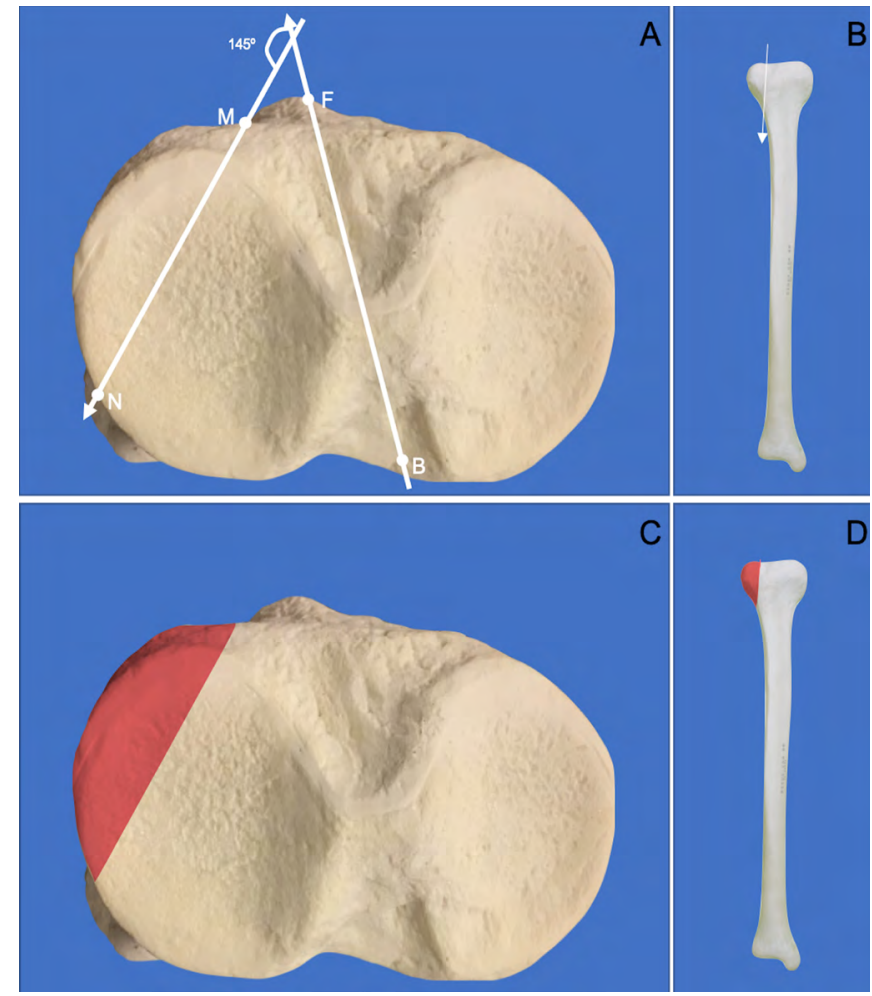

Figure 1. A, axial view of the right tibial plateau. A fracture line angle of $145^{\circ}$ was determined by measuring the angle between BF and the major fracture line $M N$, where $B$ is the middle point of the posterior cruciate ligament insertion on the tibial plateau and $F$ is the medial one-third of the tibial tuberosity. BF was used as the reference line to determine the fracture line for the experiment; $B$, coronal frontal view of the right tibial plateau. Fracture line reproduced an AL Schatzker type-I fracture (Kfuri-Schatzker type ( A); C and D, axial and coronal frontal views of the tibial plateau showing in red the fracture fragment used for the experiment.

\section{Biomechanical testing}

The tests were performed at LABIMO (Laboratório de Biomateriais em Ortopedia, Núcleo de Medicina e Cirurgia Experimental, Faculdade de Ciências Médicas, UNICAMP, Campinas, Brazil) using a universal testing machine EMIC DL-3000 (Instron-EMIC, S.J. dos Pinhais, Brazil, using a $5 \mathrm{kN}$ load cell calibrated and verified by Instron Brasil Equipamentos Científicos certification number 17041003DF, last certified on April 10, 2017). The models were fixed distally on a 3-jaw chuck, each jaw aligned to one of the vertices of the approximately triangular cross section of the tibia. The models were positioned with the long axis of the tibial shaft at $3^{\circ}$ varus and a $12.5^{\circ}$ posterior slope to simulate the normal alignment in midstance full weight bearing ${ }^{13}$.

The load was applied over the lateral tibial plateau at $6.0 \mathrm{~mm}$ lateral to the fracture line and parallel 
to it. A loading applicator with a radius of curvature of 3.5-mm was used. The load was applied at a constant strain rate of $5.0-\mathrm{mm} / \mathrm{min}$ (Figure 3 ). The outputs from the material testing machine (load and crosshead vertical displacement) were registered on the computer using the TESC 3.04 program (Instron-EMIC, S.J. dos Pinhais, Brazil). A force versus displacement curve was generated in real time.
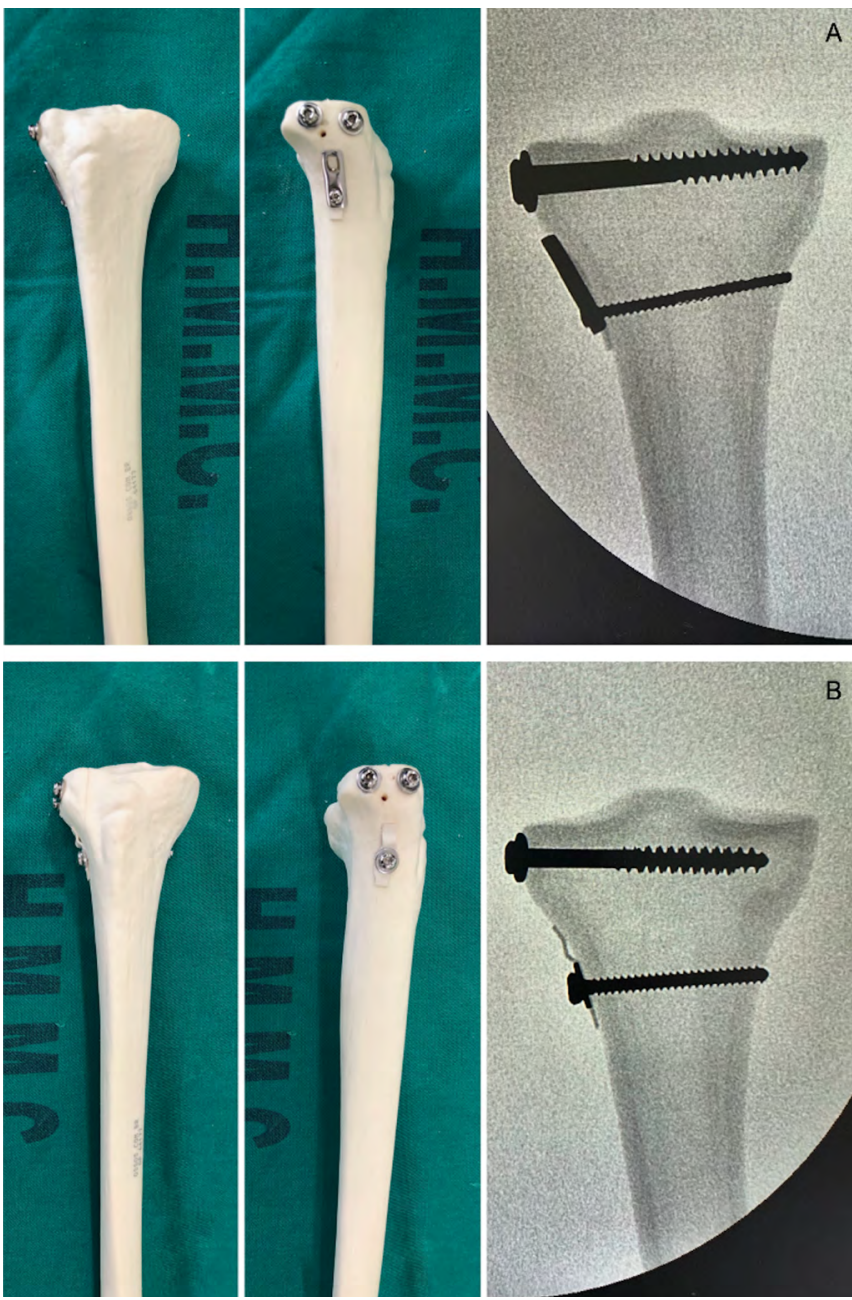

Figure 2. A, Plate-screw construction model; B, Screw-washer model Note the positioning of the buttressing implants exactly at the apex of the $A L$ fracture of the tibial plateau. Anatomic reduction was warranted both by direct vision and fluoroscopic control. Two 6.5- $\mathrm{mm}$ cancellous screws with 32-mm thread and washers were used in a juxta-articular lag-screwing fixation.

All groups were tested up to the onset of yielding, defined as the load at which the bone-plate or bone-screw and washer construction started yielding or behaving non-linearly on the computer screen ${ }^{13,14}$ The tests were performed only in the elastic phase of the models, according to the Northwestern (NU-Daniel) theory for composite materials under static and dynamic loading ${ }^{14}$
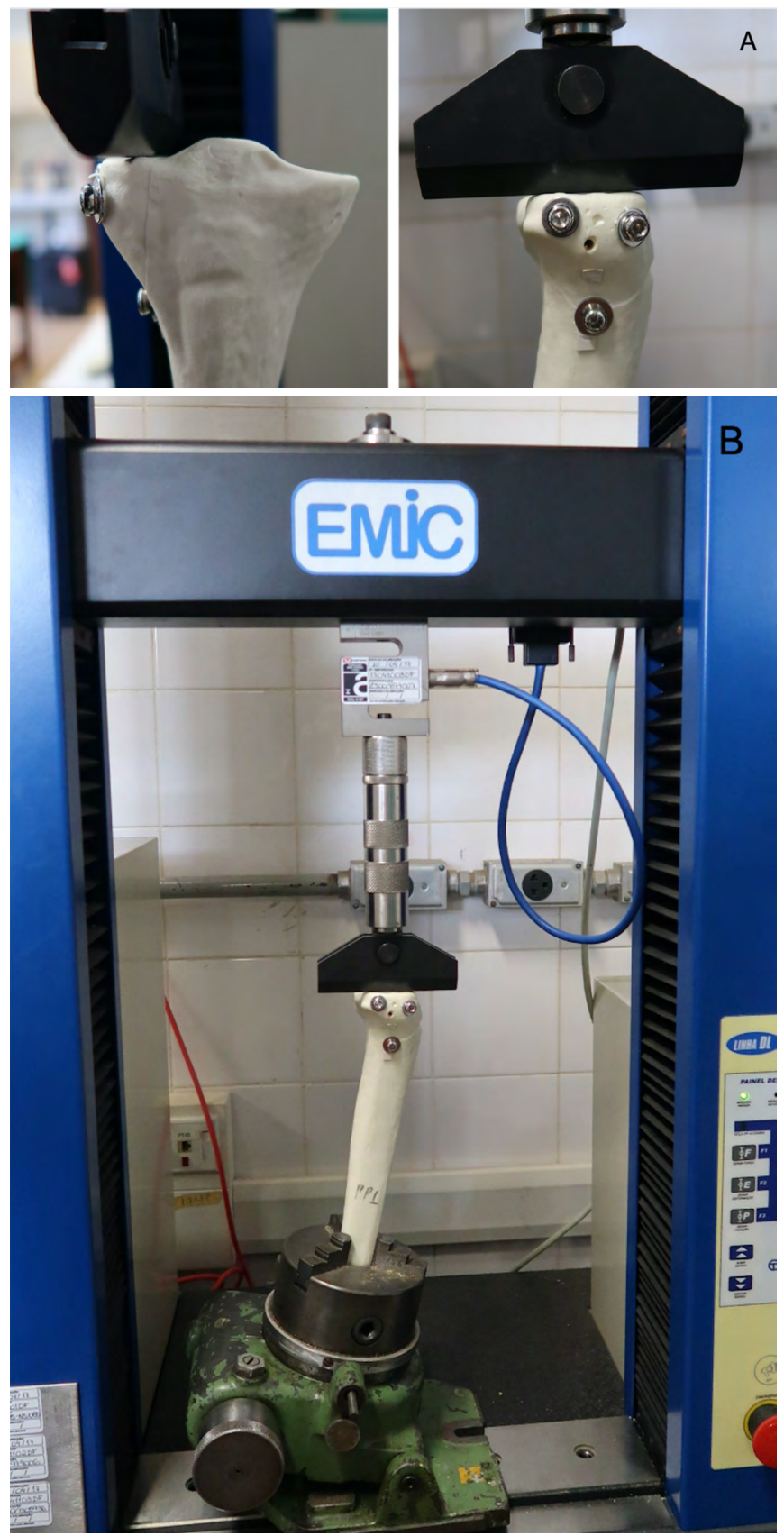

Figure 3. - A, Frontal and lateral view of the loading device with a screw-washer construction group model before testing; $B$, Universal testing machine setup for biomechanical testing.

The force versus displacement curves obtained until the onset of yielding were used to calculate stiffness of the bone-plate construction. The stiffness 
was obtained from the slope of a straight-line adjusted between $50 \mathrm{~N}$ and $250 \mathrm{~N}$. This interval was used as curves sections below $50 \mathrm{~N}$ were subject to model accommodation onto the material testing machine and curves sections above $250 \mathrm{~N}$ represented the onset of failure.

\section{Statistical analysis}

All statistical calculations were carried out using SPSS Version 20.0 (SPSS Inc, Chicago, USA). Previous to the beginning of the experiment, the size of the sample was calculated by using the type-ll error (beta-error analysis) for the student's $t$ test, with a Cohen's d effect size of 0.2 , founding a beta level (two-tailed hypothesis) of 0.967 . This was considered adequate in terms of the number of plastic bone models used.

Statistical analysis was performed to compare stiffness $(\mathrm{N} / \mathrm{mm})$ between construction groups using the nonparametric Wilcoxon rank-sum test to investigate the null hypothesis ('plate-screw construct is stiffer than plate-screw" $)^{15}$. A $p$ value of $<0.05$ was set as the level of significance.

Data presented a Gaussian distribution by not rejecting the null hypothesis, assuming that the models were normally distributed.

\section{RESULTS}

In synthetic models of plate-screw construction group, stiffness ranged from $311.83 \mathrm{~N} / \mathrm{mm}$ (specimen 8) to $199.54 \mathrm{~N} / \mathrm{mm}$ (specimen 2), with a mean + SD of $260.32+33.8 \mathrm{~N} / \mathrm{mm}$ and a CV of 13.0. Figure 4 shows force versus displacement curves obtained from the onset of yielding of specimens 8 and 2 .

In synthetic models of screw-washer construction group, stiffness ranged from $290.34 \mathrm{~N} / \mathrm{mm}$ (specimen 1) to $99.16 \mathrm{~N} / \mathrm{mm}$ (specimen 4), with a mean + SD of $220.46+63.12 \mathrm{~N} / \mathrm{mm}$ and a CV of 28.6. Figure 5 shows force versus displacement curves obtained from the onset of yielding of specimens 1 and 4 .

There was no significant difference $(p=0.172)$ between plate-screw and screw-washer construction groups. Data from both experimental groups is represented as a boxplot shown in Figure 6.

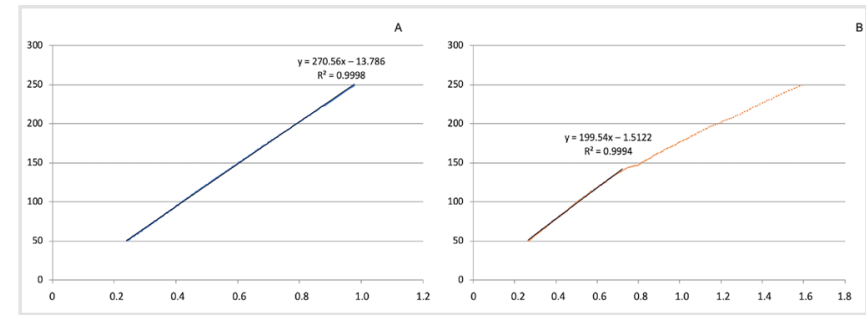

Figure 4. - Plate-screw construction group. A, Force versus displacement curve of specimen $8 ; B$, Force versus displacement curve of specimen 2.

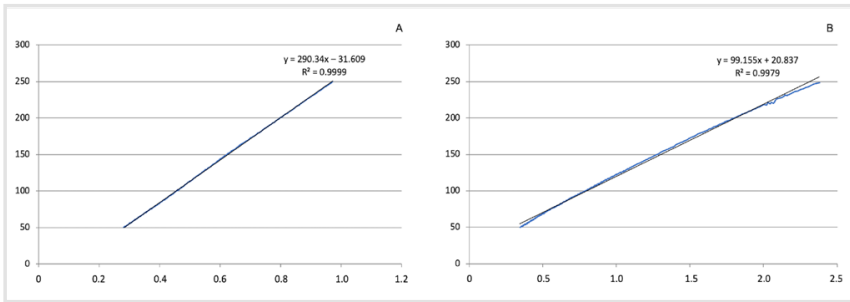

Figure 5. - Screw-washer construction group. A, Force versus displacement curve of specimen 1; B, Force versusd isplacement curve of specimen 4.

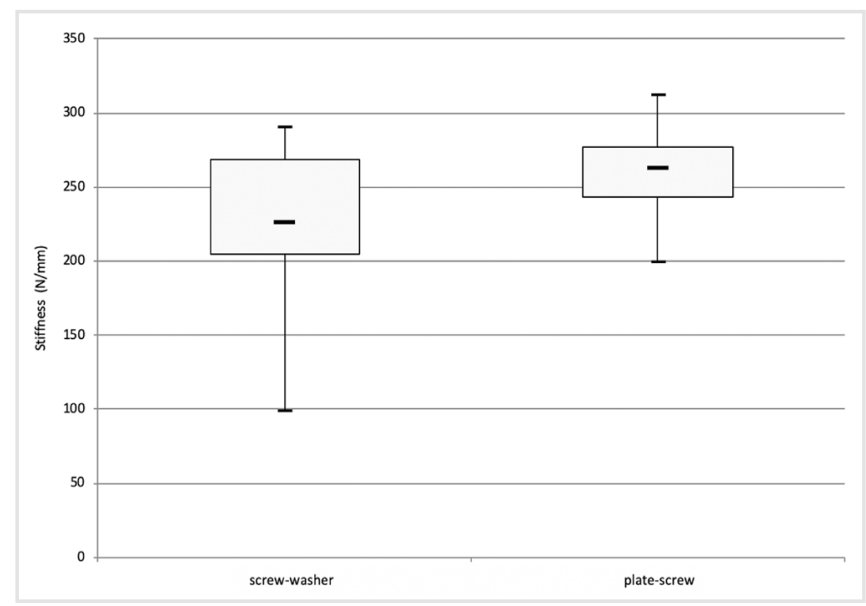

Figure 6. - Visual representation of specimens from both screw-washer and plate-screw construction groups. Note that the middle values of the dataset (median - Q2/50th percentile) were $226.06 \mathrm{~N} / \mathrm{mm}$ and 262.42 $\mathrm{N} / \mathrm{mm}$, respectively, with no significant difference between construction groups.

\section{DISCUSSION}

Based on our results, it is possible to state that either plate-screw or screw-washer construct have no significant difference on buttressing the apex of an AL Schatzker type-I tibial plateau fracture. Therefore, we could not confirm the null hypothesis that platescrew construct would provide a stiffer construction for fixation of this fracture pattern (Kfuri-Schatzker type I A). In the present study, both groups were tested up to the onset of yielding, in the elastic phase of the 
models, according to the NU-Daniel theory for composite materials under static and dynamic loading ${ }^{14}$. Following yielding, constructs are expected to behave in a nonlinear fashion up to failure initiation, as material begins to deform plastically, suffering permanent irreversible damage, clinically representing fracture subsidence, articular cartilage step-off, and late valgus collapse.

To date there is scarce evidence about the best fixation method for the AL Schatzker type-I tibial plateau fracture. Koval et al. performed a biomechanical study to compare the stability and ultimate strength of three standard fixation techniques for split-type lateral tibial plateau fractures: three $6.5-\mathrm{mm}$ cancellous lag screws with washers, two $6.5-\mathrm{mm}$ cancellous lag screws with washers and an additional antiglide 4.5$\mathrm{mm}$ cortical screw with washer, and six-hole L-shaped buttress plate $^{16}$. There were no statistically significant differences found between resistance to displacement or failure strength as a function of either fragment size or sample bone density. On the basis of their laboratory study, it was concluded that use of an antiglide screw or buttress plate does not offer an advantage over lag screw fixation alone for the treatment of split type lateral tibial plateau fractures. Differently from us, those authors used embalmed osteopenic lower extremities, which do not adequately reproduce the classic pure shear fracture of the lateral plateau, that generally occurs in younger patients, whose subchondral bone is dense enough to resist depressing the joint surface ${ }^{4}$. In addition, using synthetic models that adequately reproduce the properties of a normal bone from a young person present an advantage over fresh or frozen human bones because the setup variability of natural tibia axial stiffness is unacceptably high, indicating exceptional difficulty in obtaining reproducible bone alignment ${ }^{17-19}$.

The use of an AL buttress plate or a screw and washer at the apex of the fracture has been recommended either to prevent axial displacement when a long split is identified or when there is comminution at its metaphyseal base $e^{4,7,8,10}$. In these situations, buttressing can be useful to resist shearing forces in a normal valgusoriented knee. As the shearing forces are greatest at the last degrees of extension, vertical subsidence of the lateral tibial plateau is greatest without an antiglide plate, as demonstrated also when lateral split fragment with comminution occurs ${ }^{20}$. This impression was corroborated by a three-dimensional computed tomographic study of Chen et al., who noted the average fracture line angle of the AL Schatzker type-I tibial plateau fracture to be $145.92^{\circ} \pm 16.06^{\circ}$, highly indicative of shear instability and vertical displacement ${ }^{1}$.

Our study has some strengths that should be mentioned. First, we used a reproducible model of AL Schatzker type-I tibial plateau fracture, based on 3-D computed tomography'. Second, we were able to adjust for many variables, such sample size, positioning of the models and point of load application during biomechanical testing, and statistical analysis, which ultimately could impact our methodology. Finally, our results showed no significant difference between experimental construction groups, allowing the surgeon greater freedom of choice of the technique used to buttress the apex of an AL Schatzker type-I tibial plateau fracture.

Also, the present study has few limitations that should be recognized. First, synthetic tibiae may not reflect the actual conditions of bone properties. However, similar biomechanical studies have demonstrated good reproducibility using plastic bones to evaluate different assemblies for fixation of tibial plateau fractures ${ }^{13,20,21}$. The use of composite tibiae allows small differences to be characterized significantly, even when a small sample is used. Secondly, the synthetic models used reproduced the properties of a normal rather than osteoporotic bone. However, most pure shear fractures of the lateral tibial plateau occur in individuals from the fourth and fifth decades of life, in which satisfactory bone stock is assumed ${ }^{5}$. Finally, we did not have an experimental group without a buttressing device. Relatively old literature has not supported the use of either a buttress plate or buttressing screw and washer placed at the apex lateral tibial plateau for pure shear fractures ${ }^{16,22}$. However, in a more recent study, Carrera et al. have shown the biomechanical role of additional buttressing for the sheartype tibial plateau fracture, with a higher reaction force on the lateral metaphyseal wall attributed to the additional caudal support ${ }^{23}$. Conceptually, buttressing neutralizes vertical shearing forces mainly during axial loading and prevents sliding of the fracture fragment ${ }^{11,24}$. Hence, the anti-glide effect transforms shearing forces into 
compression forces within the fracture with axial loading. Conflicts of interest

\section{CONCLUSION}

In pure split AL Schatzker type-I tibial plateau fracture (Kfuri-Schatzker type | A), a two-hole smallfragment non-locked plate with one 3.5-mm bicortical screw inserted at $1.0 \mathrm{~mm}$ distal to the apex of the fracture or a 4.5-mm bicortical screw with a washer applied to the anterolateral apex of the fracture as buttressing present similar stiffness in terms of preventing axial displacement in synthetic tibiae models tested up to the onset of yielding.

Thus, in clinical situation, authors routinely recommend using one of the two fixation techniques. Future studies can evaluate the role of locked implants compared to non-locked implants for buttressing an $\mathrm{AL}$ Schatzker type-I (Kfuri-Schatzker type I A) tibial plateau fracture.
We wish to confirm that there are no known conflicts of interest associated with this publication and there has been no significant financial support for this work that could have influenced its outcome. We confirm that the manuscript has been read and approved by all named authors and that there are no other persons who satisfied the criteria for authorship but are not listed. We further confirm that the order of authors listed in the manuscript has been approved by all of us.

We confirm that we have given due consideration to the protection of intellectual property associated with this work and that there are no impediments to publication, including the timing of publication, with respect to intellectual property. In so doing we confirm that we have followed the regulations of our institutions concerning intellectual property.

\title{
RES U M O
}

\begin{abstract}
O objetivo do estudo foi avaliar o comportamento biomecânico de dois tipos de fixação: placa de compressão dinâmica de pequenos fragmentos, não bloqueada com parafuso de $3,5 \mathrm{~mm}$ e parafuso cortical de 4,5mm com arruela, ambos posicionados no vértice de fratura do platô tibial do tipo I de Schatzker. Dezesseis tibias sintéticas foram utilizadas para criar uma fratura por cisalhamento na face ântero-lateral do platô tibial (tipo I de Schatzker). Oito modelos foram fixados com placa de compressão dinâmica de pequenos fragmentos não bloqueada com parafuso de $3,5 \mathrm{~mm}$, inserido $1,0 \mathrm{~mm}$ distal ao vértice da fratura (construção placa-parafuso), e oito modelos foram fixados com parafuso cortical de 4,5mm com arruela, inserido 1,0 mm distal ao vértice da fratura (construção parafusoarruela). Os modelos foram testados em compressão axial até o início da falha mecânica na interface construção-osso, com taxa de deformação constante de 5,0mm/min. A rigidez variou de 311,83 N/mm a 199,54 N/mm, com média + DP de 260,32 + 33,8 N/mm nos modelos da construção placa-parafuso, e de 290,34 N/mm a 99,16 N/mm, com média + DP de 220,46 + 63,12 N/mm nos modelos da construção parafuso-arruela. Não houve diferença estatisticamente significativa $(p=0,172)$. A utilização de placa de compressão dinâmica de pequenos fragmentos não bloqueada com parafuso de 3,5mm ou de parafuso cortical de 4,5mm com arruela, posicionados no vértice da fratura do platô tibial do tipo I de Schatzker, apresenta rigidez similar na prevenção do desvio axial da fratura.
\end{abstract}

Palavras chave: Platô Tibial. Estudo Biomecânico. Técnicas de Fixação.

\section{REFERENCES}

1. Chen P, Shen H, Wang W, Ni B, Fan Z, Lu H. The morphological features of different Schatzker types of tibial plateau fractures: a three-dimensional computed tomography study. J Orthop Surg Res. 2016;11(1):94.

2. Liu Y, Liao Z, Shang L, Huang W, Zhang D, Pei G. Characteristics of unilateral tibial plateau fractures among adult patients hospitalized at an orthopaedic trauma centre in China. Sci Rep. 2017;7:40647.

3. Molennars RJ, Mellema JJ, Doornberg JN, Kloen P. Tibial plateau fracture characteristics: computed tomography mapping of lateral, medial, and bicondylar fractures. J Bone Joint Surg Am. 2015;97(18):151220.

4. Kfuri M Jr, Fogagnolo F, Bitar RC, Freitas RL, Salim R, Paccola CAJ. Tibial plateau fractures. Rev Bras Ortop. 2009;44(6):468-74.

5. Albuquerque RP, Hara R, Prado J, Schiavo L, Giordano $\checkmark$, Amaral NP. Epidemiological study on tibial plateau fractures at a level I Trauma Center. Acta Ortop Bras. 2013;21(2):109-15.

6. Koval KJ, Helfet DL. Tibial plateau fractures: evaluation and treatment. J Am Acad Orthop Surg. 1995;3(2):86- 
94.

7. Musahl V, Tarkin I, Kobbe P, Tzioupis C, Siska PA, Pape HC. New trends and techniques in open reduction and internal fixation of fractures of the tibial plateau. J Bone Joint Surg Br. 2009:91(4):426-33.

8. Sirkin MS, Bono CM, Reilly MC, Behrens FF. Percutaneous methods of tibial plateau fixation. Clin Orthop Rel Res. 2000;(375):60-8.

9. Salduz A, Birisik F, Polat G, Beler B, Bozdag E, Kilicoglu $O$. The effect of screw thread length on initial stability of Schatzker type 1 tibial plateau fracture fixation: a biomechanical study. J Orthop Surg Res. 2016;11(1):146.

10. Denny LD, Keating EM, Englhardt JA, Saha S. A comparison of fixation techniques in tibial plateau fractures. Orthop Trans. 1985;10:388.

11. Kfuri M, Schatzker J. Revisiting the Schatzker classification of tibial plateau fractures. Injury Int J Care Injured. 2018;49(12):2252-63.

12. Schatzker J, McBroom R, Bruce D. The tibial plateau. The Toronto experience 1968-1975. Clin Orthop Rel Res. 1979;(138):94-104.

13. Ali AM, Saleh $M$, Bolongaro $S$, Yang L. Experimental model of tibial plateau fracture for biomechanical testing. J Biomech. 2006;39(7):1355-60.

14. Daniel IM. Yield and failure criteria for composite materials under static and dynamic loading. Prog Aerosp Sci. 2016;81:18-25.

15. Hollander $M$, Wolfe DA. Nonparametric statistical methods. 2. ed. New York: John Wiley \& Sons; 1999.

16. Koval KJ, Polatsch D, Kummer FJ, Cheng D, Zuckerman JD. Split fractures of the lateral tibial plateau: evaluation of three fixation methods. J Orthop Trauma. 1996;10(5):304-8.

Recebido em: 29/03/2020

Aceito para publicação em: 22/04/2020

Conflito de interesses: não.

Fonte de financiamento: nenhuma.
17. Cristofolini L, Viceconti M. Mechanical validation of whole bone composite tibia models. J Biomech. 2000;33(3):279-88.

18. Heiner AD. Structural properties of fourthgeneration composite femurs and tibias. J Biomech. 2008;41(15):3282-4.

19. Heiner $A D$, Brown TD. Structural properties of a new design of composite replicate femurs and tibias. J Biomech. 2001;34(6):773-82.

20. Karunakar MA, Egol KA, Peindl $R$, Harrow ME, Bosse MJ, Kellam JF. Split depression tibial plateau fractures: a biomechanical study. J Orthop Trauma. 2002;16(3):172-7.

21. Giordano V, Kfuri M, Belangero W, Venturini $A$, Silva $A C$, Soares EM, et al. Non-locked and locked small fragment straight plates have a similar behavior in buttressing the posteromedial shear tibial plateau fragment: a biomechanical analysis of three different fixations. J Exp Orthop. 2020;7(1):2.

22. Koval KJ, Sanders R, Borrelli J, Helfet D, DiPasquale T, Mast JW. Indirect reduction and percutaneous screw fixation of displaced tibial plateau fractures. J Orthop Trauma. 1992;6(3):340-6.

23. Carrera I, Gelber PE, Chary G, González-Ballester MA, Monllau JC, Noailly J. Fixation of a split fracture of the lateral tibial plateau with a locking screw plate instead of cannulated screws would allow early weight bearing: a computational exploration. Int Orthop. 2016;40(10):2163-9.

24. Giordano V, Amaral NP, Koch HA, Albuquerque RP, Souza FS, Santos-Neto JF. Outcome evaluation of staged treatment for bicondylar tibial plateau fractures. Injury Int J Care Injured. 2017;48S4(4):S34S40.

\section{Endereço para correspondência:}

Vincenzo Giordano

E-mail:v_giordano@me.com

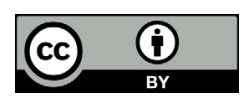

